\title{
Location Quotient Analysis (LQ) in Determining the Excellent Commodity
}

$1^{\text {st }}$ Yogi Sugiarto Maulana

Department of Business

Adminisstration

STISIP Bina Putera Banjar

Banjar, Indonesia

yogi.sm@stisipbp.ac.id

$4^{\text {th }}$ Ratningsih

Department of Accounting Information System

Universitas Bina Sarana Informatika

Bogor, Indonesia

ratningsih@bsi.ac.id

\author{
$2^{\text {nd }}$ Andri Helmi Munawar \\ Faculty of Economic and Business \\ Universitas Siliwangi \\ Tasikmalaya, Indonesia \\ andri.helmi@unsil.ac.id
}

$5^{\text {th }}$ Taufik Wibisono

Department of Information System

Universitas Bina Sarana Informatika

Tasikmalaya, Indonesia

wibisono@bsi.ac.id

\author{
$3^{\text {rd }}$ Dian Hadiani \\ Department of Business \\ Adminisstration \\ STISIP Bina Putera Banjar \\ Banjar, Indonesia \\ dian.hadiani2017@gmail.com
}

\begin{abstract}
This research is done with the aim to analyze the determination of the excellent commodity in the sub-district Purwaharja Banjar City which subsectors are base and nonbase. In this research, researchers compare the type of business in the small and medium industries (IKM) Purwaharja Subdistrict with Banjar City with a labor approach in the base and non-base IKM sector in Purwaharja sub-district of 655 people and in Banjar City as much as 3229 people. The data collected is then analyzed using the Location Quotient (LQ) analysis. The results of the analysis showed that the district Purwaharja has 7 types of businesses that are the basis. The first and second rank with the value of $4.92977 \mathrm{LQ}$ is the business type of bamboo crafts and pallets. The third base type of business is a type of business/production Ranginang with LQ of 4.48161. The next position in a row is the type of business/bread production with the value LQ 3.10393, Sale banana 1.89954, red brick 1.74123 , and salted egg with the value of LQ 1.03785. Thus it can be said that bamboo crafts, pallets, ranginang, bread, sale bananas, red brick, and salted eggs are a base sector in the sub-district Purwaharja.
\end{abstract}

Keywords-commodities, featured, location, development, region

\section{INTRODUCTION}

The determination of the leading commodity in an area is the first step towards development that rests on the concept of efficiency to achieve a conjugative and competitive advantage in dealing with the trading globalization faced [1]. The step towards efficiency can be reached by using commodities that have comparative advantages both reviewed from the supply and demand side. From the offering side, the flagship commodity is characterized by the strength in growth in physical conditions, technology, and socio-economic conditions that can be made a mainstay to increase revenue. From the demand side, the flagship commodity is characterized by strong demand in both domestic and international markets. Various approaches and analytical tools have been widely used to identify excellent commodities, using several technical and non-technical criteria in the framework of fulfilling supply and demand aspects [2].
Each approach has advantages and disadvantages, so choosing analisis method to determine this superior commodity needs to be done carefully and wisely [3]. One of the approaches that can be used to analyze excellent commodities is the Location Quotion (LQ) method [4].

The study of the changing role of soybeans in the food system in China discussing the aspects of production, processing, and consumption and trade, one of its analytical tools using the approach of LQ [5]. Also other study using LQ for their analytical tools [6] [7] [8] [9]. Study of Mapping the Sectoral Concentration of the Workforce Across Eu Regions, 2009-2013 [10]. Likewise in Indonesia, for example the Center for food Crops Research and development (Puslitbangtan) in discussing the soybean commodity system also use this model LQ [11]. Impact of economic crisis to labor opportunities and to identify the major commodities of the agricultural sector in Sulawesi [12]. Based on the understanding of the base economic theory, relevant LQ techniques are used as a method of determining the flagship commodity in Purwaharja subdistrict.

\section{METHOD}

Location Quotion Analysis (LQ) is a comparison of the role of a sector/industry in a region/city against the role of a sector/industry in the province [13]. There are two ways to measure the LQ of a sector in an economic area i.e. through a value-added approach or PDRB (gross Regional domestic product) and labor [14].

In this research, researchers compare the type of business in the small and medium industries (IKM) Purwaharja subdistrict with Banjar City with a workforce approach. This analysis was conducted to determine the type of business in the base and non-base IKM sector in Purwaharja subdistrict. The formula is as follows [4]:

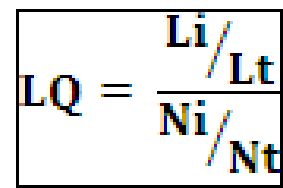


Where:

Li: The number of workers in the business type $\mathrm{I}$ in Purwaharja subdistrict

Lt: Number of manpower in Purwaharja subdistrict

$\mathrm{Ni}$ : Number of workers in the type of business I in Banjar City

$\mathrm{Nt}$ : Number of manpower in Banjar City

To interpret LQ analysis results:

1) If the value of LQ is more than (>) 1 , indicates the occurrence of the production concentration of a commodity/business at the district level relative to the total city of Banjar or there is activity concentration in the district. Or there is a surplus of production in the subdistrict and the commodity is a base sector in the district.
2) If the value of $L Q$ is equation (=) 1 , indicates that the district Purwaharja has production activity equivalent to Banjar City.

3) If the value of LQ is less than $(<) 1$, the district Purwaharja has a relatively smaller share compared with the production activity of Banjar City, or there has been a production deficit in the district Purwaharja.

\section{RESULTS AND DISCUSSION}

To find out the potential of small and medium industrial sub-sub sectors in Purwaharja sub-district used the Location Quotient (LQ) analysis with a workforce approach that is in small and medium-sector Sub-sectors (IKM). This analysis is used to determine which subsectors are base and non-base. The number of workers based on the type of business in the sector of small and medium industries in Purwaharja subdistrict is as follows:

TABLE I. The Number of Workers BASEd on the SECTOR OF SMALl AND MEDIUM INDUSTRIES IN YeAR 2018

\begin{tabular}{|l|l|l|l|}
\hline No & \multicolumn{1}{|c|}{ Type Product } & Purwaharja & \multicolumn{1}{c|}{ Banjar City } \\
\hline 1 & Red brick & 468 & 1325 \\
\hline 2 & Embroidery & 5 & 32 \\
\hline 3 & Coconut sugar & 2 & 1267 \\
\hline 4 & Bamboo Crafts & 11 & 11 \\
\hline 5 & Chips & 3 & 29 \\
\hline 6 & Convection & 5 & 81 \\
\hline 7 & Meubelair & 30 & 256 \\
\hline 8 & Palette & 18 & 18 \\
\hline 9 & Ranginang & 50 & 55 \\
\hline 10 & Bread & 17 & 27 \\
\hline 11 & Banana Sale & 42 & 109 \\
\hline 12 & Salted egg & 4 & 19 \\
\hline & Total & 655 & 3229 \\
\hline
\end{tabular}

Based on table II above the number of workers in the small and medium industrial sector (IKM) in Purwaharja Subdistrict as many as 655 people. The highest amount of manpower is on the type of business/production of red brick with a total workforce of 468 people. Following on stage two are laboring on the type of business/production Ranginang with a total workforce of 50 people.

Unlike the number of workers in each type of business in Banjar, the most number of workers are in the business type of red brick with a number of manpower as much as 1,325 people. Followed by the second position of the coconut sugar business type as much as 1,267 people.

Subsequently the data was analyzed using the Location Quotient (LQ) analysis. The LQ analysis is used to determine which small and medium industrial subsectors are the base and non-base activities in Purwaharja sub-district. The criteria of this analysis if the result LQ $>1$ Then the activities of the sub-sector of the industry is said to be the base sub sector, whereas when the LQ $<1$ then the activities of sub-sector industry is said to non-base The LQ calculation results can be seen as follows:

TABLE II. LOCATION QUOTION CALCUlation Result (LQ) PURWAHARJA SUB-District YeAR 2018

\begin{tabular}{|l|l|l|l|l|l|l|l|}
\hline No & \multicolumn{1}{|c|}{ Type Product } & Purwaharja & Banjar City & Li/Lt & Ni/Nt & Lesult \\
\hline 1 & Red brick & 468 & 1325 & 0.7145 & 0.41034 & 1.74123 \\
\hline 2 & Embroidery & 5 & 32 & 0.00763 & 0.00991 & 0.77028 \\
\hline 3 & Coconut sugar & 2 & 1267 & 0.00305 & 0.39238 & Non & 0.00778 \\
\hline 4 & Bamboo Crafts & 11 & 11 & 0.01679 & 0.00341 & 4.92977 \\
\hline 5 & Chips & 3 & 29 & 0.00458 & 0.00898 & 0.50998 \\
\hline 6 & Convection & 5 & 81 & 0.00763 & 0.02509 & Non & 0.30431 \\
\hline 7 & Meubelair & 30 & 256 & 0.0458 & 0.07928 & 0.57771 \\
\hline 8 & Palette & 18 & 18 & 0.02748 & 0.00557 & Non & 4.92977 \\
\hline 9 & Ranginang & 50 & 55 & 0.07634 & 0.01703 & Basic & 4.48161 \\
\hline 10 & Bread & 17 & 27 & 0.02595 & 0.00836 & 3.10393 \\
\hline
\end{tabular}




\begin{tabular}{|l|l|l|l|l|l|l|l|}
\hline No & \multicolumn{1}{|c|}{ Type Product } & Purwaharja & Banjar City & \multicolumn{1}{|c|}{$\mathbf{L i} / \mathbf{L t}$} & \multicolumn{1}{|c|}{ Ni/Nt } & \multicolumn{1}{c|}{ LQ } & Result \\
\hline 11 & Banana Sale & 42 & 109 & 0.06412 & 0.03376 & 1.89954 & Basic \\
\hline 12 & Salted egg & 4 & 19 & 0.00611 & 0.00588 & 1.03785 & Basic \\
\hline & Total & 655 & 3229 & 1 & 1 & & \\
\hline
\end{tabular}

Based on table 2 above, it can be identified that the type of business/Prosuksi which is a type of business/production base and non-base. Purwaharja Sub-District has 7 types of businesses that are base. The first and second rank with the value of $4.92977 \mathrm{LQ}$ is the business type of bamboo crafts and pallets. The third base type of business is a type of business/production Ranginang with LQ of 4.48161. The next position in a row is the type of business/bread production with the value LQ 3.10393, Sale banana 1.89954, red brick 1.74123, and salted egg with the value of LQ 1.03785.

For more details about the level of LQ in Purwaharja subdistrict can be seen on the chart as follows:

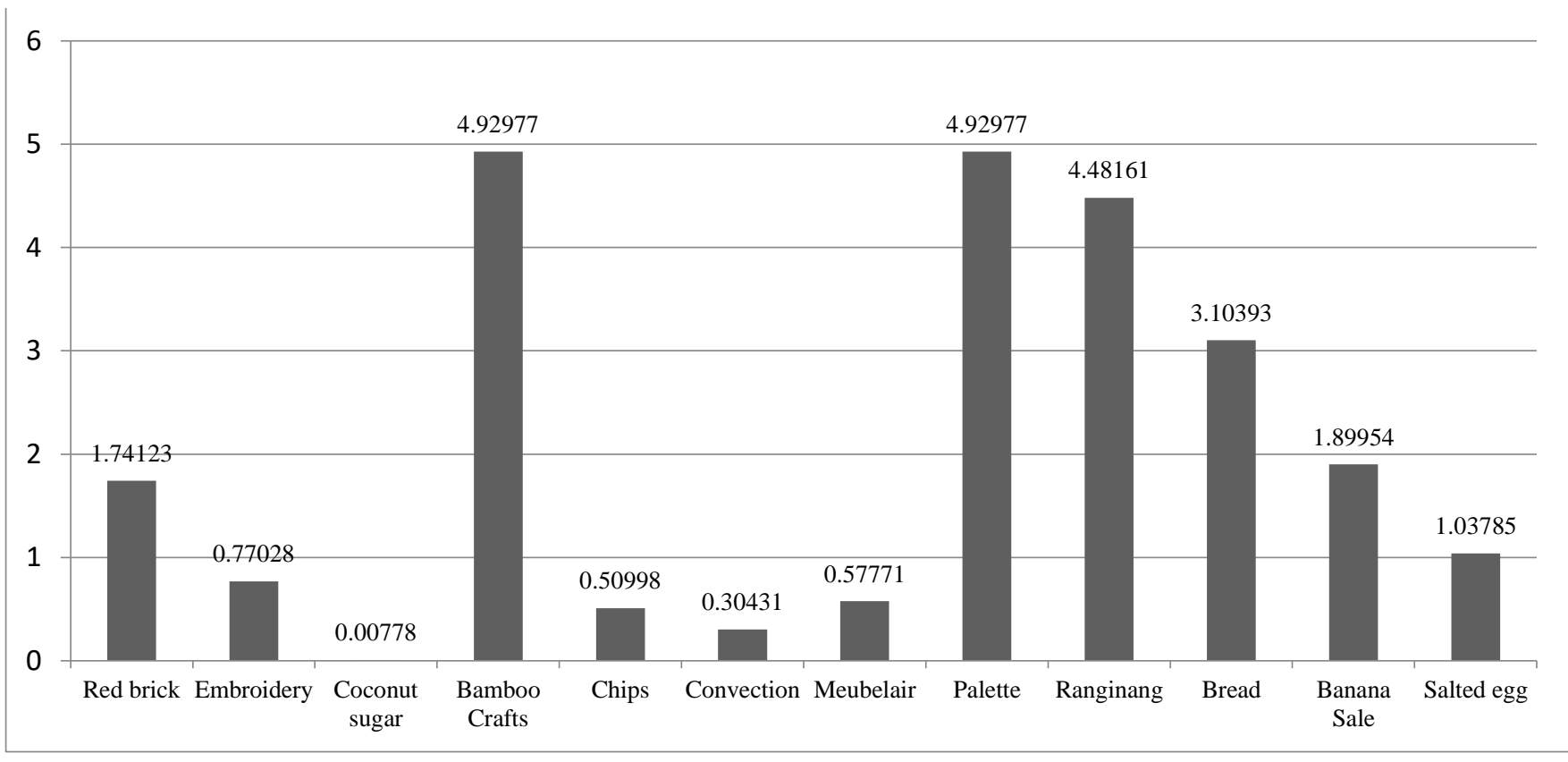

Fig. 1. Location quotion graph (LQ) of purwaharja subdistrict Year 2018

Analysis results can be explained that the value of LQ in sub-district Purwaharja which has a value greater than 1 (LQ >1) There are 7 types of business/production namely bamboo crafts, pallets, ranginang, bread, sale bananas, red brick, and salted eggs. Thus it can be said that the 7 types of business is a base sector in the district Purwaharja. Commodities that produce the value of LQ > 1 are normative standards to be designated as superior commodities. However, when many commodities in an area that produces LQ > 1, while the one sought only, then that should be chosen is the commodity that gets the highest value of LQ. Because the higher LQ value in a region shows the higher the potential of the commodity.

The role of a commodity will be more prominent in an area when it has a value of LQ >, so that from the commodity sector can export a part of its production. This is inversely proportional when the commodity has an LQ value of $<1$, meaning that the commodity sectors are not able to meet the local market needs and tend to import from other regions.

The flagship product of the region is a superior product that has the characteristic and uniqueness that is not owned by other regions and reliable competitiveness and can provide opportunities for employment opportunities to local people. The region's flagship products are also environmentally friendly and are oriented to both local and national markets and export market oriented. The development of superior products is an effective strategy in the development of regional economies. Therefore, the development of superior products as the economic potential of the region in the era of autonomy is a work that is not easy to implement. This is because the development of the regional superior products closely related to the political will or policy of the local government. Therefore, the role of local government is very important in the development and empowerment of the region's flagship product as one of the acceleration and expansion efforts of the regional economic development.

\section{CONCLUSION}

Top commodities in Purwaharja sub-district of Banjar City based on Location Quotient analysis (LQ) The first is a bamboo handicrafts and pallets with a value of $4.92977 \mathrm{LQ}$, business/production Ranginang with LQ of 4.48161, next in a row that is the type of business/bread production with the value of LQ 3.10393, sale banana 1.74123 1.89954 Thus it can be said that the 7 types of business is a base sector in the district Purwaharja.

\section{ACKNOWLEDGMENT}

Thanks to head of department of cooperation, small businesses, middle and trade has invited us to implement this study.

\section{REFERENCES}

[1] A. M. Isserman, "The location quotient approach to estimating regional economic impacts,” J. Am. Inst. Plann., vol. 43, no. 1, pp. 33-41, 1977.

[2] R. Hendayana, "Aplikasi metode Location Quotient (LQ) dalam 
penentuan komoditas unggulan nasional," Inform. Pertan., vol. 12, no.

[3] G. KOL'VEKOVÁ, and D. PALAŠČÁKOVÁ, "Calculation of localization quotient for employment in cities of Slovakia-prešov and košice. Principles of changes in employment of the productive people," J. Appl. Econ. Sci., vol. 12, no. 2, pp. 604-614, 2017.

[4] L. Arsyad, Ekonomi Pembangunan, Jakarta: Universitas Terbuka, 2014.

[5] C. Aubert, and Z. Xigang, The changing role of soybean in China's food system: a study in its production, processing, consumption and trade, China agriculture press, 2002.

[6] A. T. Flegg, L. J. Mastronardi, and C. A. Romero, "Evaluating the FLQ and AFLQ formulae for estimating regional input coefficients: empirical evidence for the province of Córdoba, Argentina," Econ. Syst. Res., vol. 28, no. 1, pp. 21-37, 2016.

[7] F. Niyimbanira, "Comparative advantage and competitiveness of main industries in the north-eastern region of South Africa: Application of location quotient and shift-share techniques," Int. J. Econ. Financ. Stud., vol. 10, no. 1, pp. 96-114, 2018.

[8] A. E. Cahyono, and A. Santoso, "Local Superior Commodities, Regional Specializations and Regional Economic Contributions," 유통과학연구, vol. 16, no. 9, pp. 35-41, 2018.

[9] A. Crawley, and M. Munday, "Priority sectors in city regions? Some issues from a study of the Cardiff Capital Region," Local Econ., vol. 32, no. 6, pp. 576-589, 2017.

[10] E. Vgenopoulou, G. Economou, and P. Prodromidis, "Mapping The Sectoral Concentration Of The Workforce Across Eu Regions, 20092013,” Reg. Sci. Inq., vol. 8, no. 1, pp. 85-98, 2016.

[11] D. Aman, "The Soybean commodity system in Indonesia," Journal, p. 93, 1985.

[12] N. Syafaat, and S. Friyatno, "Analisis Dampak Krisis Ekonomi Terhadap Kesempatan Kerja dan Identifikasi Komoditas Andalan Sektor Pertanian di Wilayah Sulawesi: Pendekatan Input-Output," Ekon. Keuangan Indones., vol. 48, no. 4, pp. 369-393, 2000.

[13] R. Tarigan, Ekonomi Regional Teori dan Aplikasi Edisi Revisi, Jakarta: Bumi Aksara, 2005.

[14] A. Daryanto, Pembangunan Sektor Perikanan Berbasiskan Klaster, 